\title{
OLD TURKIC RELIGIOUS BELIEFS AS A PART OF SPIRITUAL CULTURE OF TURKIC-SPEAKING PEOPLES OF THE CRIMEA
}

\author{
(C) Irina K. Zholobova \\ Rostov State Medical University, Rostov-on-Don, Russian Federation \\ science-almanac@mail.ru
}

The peculiarities of worldview and spiritual culture of Turkic people are considered, due to general historical, ethnogenetic, cultural and religious factors. The influence of the old Turkic nomadic component on the formation of the religious system and ethnoculture of peoples is noted. The main attention is paid to the features of the cult associated with the veneration of the most ancient deity Tengri, references to which are still found and indicate the syncretic nature, the presence of assimilated autochthonous beliefs in religious systems, in the part of spiritual culture of such Turkic-speaking peoples as the Crimean Karaites, the Crimeans and the Crimean Tatars. Information about Tengrianism is given, the characteristic of cult practice in relation to Heaven is given, the significance of the cult of ancestors and the cult of veneration of sacred trees is noted, which have until recently remained relevance for the indigenous peoples of the Crimea, especially for the Crimean Karaites.

Key words: Tengri, religion, the Crimea, Tengrianism, religious beliefs, folklore, the Crimean Karaites, the Crimeans, cult of ancestors.

\section{[И.К. Жолобова Древнетюркские религиозные верования как часть духовной культуры тюркоязычных народов Крыма]}

Рассматриваются особенности мировоззрения, духовной культуры тюрков, обусловленные общими историческими, этногенетическими, культурологическими и религиозными факторами. Отмечается влиянием древнетюркского кочевого компонента на формирование религиозной системы и этнокультуры народов. Основное внимание уделяется особенностям культа, связанного с почитанием древнейшего божества Тенгри, упоминания о котором встречаются до сих пор и свидетельствуют о синкретическом характере, наличии ассимилированных автохтонных верований в религиозных системах, части духовной культуры таких тюркоязычных народов, как крымские караимы, крымчаки и крымские татары. Приводятся сведения о тенгрианстве, даётся характеристика культовой практики по отношению к Небу, отмечается значимость культа предков и культа почитания священных деревьев, которые вплоть до недавнего времени сохраняли свою актуальность для коренных народов Крыма, особенно, для крымских караимов.

Ключевые слова: Тенгри, религия, Крым, тенгрианство, религиозные верования, фольклор, крымские караимы, крымчаки, культ предков.

Irina K. Zholobova - Assistant, Rostov State Medical University, Rostov-on-Don, Russian Federation.

Жолобова Ирина Константиновна - ассистент, Ростовский государственный медицинский университет, г. Ростов-на-Дону, Российская Федерация.

At present, in addition to studying the key trends and perspectives associated with the ongoing processes of globalization, special attention is paid to various aspects of ethnic culture, the definition of the foundations of spiritual development of peoples, factors that contribute to the preservation of their religious and ethnic identity.

Religion, like the entire spiritual culture of peoples, has evolved and undergone significant changes over the centuries. At the same time, in the culture of ethnic groups at all times there were transformational and stabilizing factors that contributed to the creation of new value guidelines [6; 7] on the way to the historical development of the ethnic group. 
The components, that make up the religious tradition, were preserved, transformed under the influence of cultural, historical and social conditions, or died out.

Interrelated constructive elements of ancient beliefs played an important role in the formation of a peculiar perception of the world and contributed to harmonious coexistence with the surrounding world. The study of the formation of the world perception of people through the prism of religious cults and mythological subjects allows us to trace the development of the cultural and worldview environment of peoples. In this regard, the consideration of the system of symbols, worldview principles, the national picture of the world, the reproduction of which is most visible in the system of beliefs and folklore, is of paramount importance [14, pp. 25-26, 28]. It is "folklore as a component of spiritual culture that reflects the traditional picture of the world of the people, which is based on archaic views and ancient beliefs. Traces of mythological representations and ancient beliefs have been preserved in rites and folklore works of various genres. Despite the geographical distance of peoples... traditional rites and folklore retain common elements, which can indicate common ethnic roots" [11, p. 70].

In particular, folklore and religious ideas of Turkic-speaking peoples are characterized by many common features, which is explained by the kinship ties of these peoples, their ethnic and linguistic community.

Common historical, ethnogenetic, cultural and religious factors have determined the commonality and internal kinship of such Turkic-speaking peoples living in the territory of the Crimea peninsula, such as the Crimean Tatars, the Crimean Karaites, the Crimeans. It is important to note that the issue of the ethnicity of the Karaites and the Crimeans is the subject of constant discussion; however, relying on a number of studies $[1 ; 2 ; 10 ; 11]$ we will also adhere to the point of view repeatedly voiced by the leaders of these peoples that the Crimean Karaites and the Crimeans are a special Turkic people.

These peoples have got common ethnogenetic and cultural roots. So, in particular, the common Khazar layer, uniting the Crimean Karaites and the Crimeans, was noted by A.N. Samoilovich, who defined the existing ties between them, "as echo of cultural, and nonlinguistic relations in the era of the Khazar kingdom" [11, p. 71].

The increased interest in the history and peculiarities of the culture of the indigenous peoples of the Republic of Crimea is largely due to the socio-cultural, political and current problems of our time. Turkic ethnic groups have a significant role in the ethnopolitical history of the peninsula. They influenced the appearance of the Crimean Khanate and the Turkish Sanjak, the existence of which lasted until the end of the 18th century. The Crimean Tatars, the Karaites, the Crimeans are ethnic groups, each of which has its own special identity, and at the same time, many common features due to both common ancestors and close interaction in the territory of the Crimea. Many specialists are attracted to identity, cultural and historical origins and connections with various religious and mythological systems, the syncretic nature of religion and echoes of ancient Turkic religious beliefs that persist in their spiritual culture to this day.

The Old Turkic nomadic component of Turkic-speaking ethnic groups determined a rather complex representation of the world order, as well as their understanding of the "plurality" of their own history and identity. It is interesting to turn to the concept of "nomadology" ("science of nomads"), formulated as a specific model by philosophers such as Gilles Deleuze and Félix Guattari. In their opinion, the nomad, unlike a representative of a settled type of culture, is characterized by a fundamentally different way of life and, accordingly, a different type of rationality: mobile, light, decentralized, with many variants (plural).

"Tengrianism" is traditionally considered as an ancient Turkic religious system, which, according to A.A. Kodar, "has two modes of existence: folk and imperial" [9]. At the same 
time, it is assumed that as a tribal cult, a belief system, it could exist for millennia, and as a monotheistic religion developed only in the era of the Old Turkic Kaganate.

Ayupov N.G. uses two concepts "Тәңір ді" (Tengrianism) as a religion and " Тәңіршилиқ" as a worldview. "The world is mastered and understood through Tengrianism, it acts as a kind of principle, the basis of attitude to everything, Tengrianism is not just a guide, a doctrine for man, but it is inside him, it is his way of life, a life-purpose process" [3, p. 24].

The key feature of Tengrianism is the absence of a specialized group, a social layer, a caste of ministers of the cult (shamans, priests, clergy). In addition, the Turks created neither portraits nor statues in their worship of the original and eternal God that gave the Kagans Qut, Ulug (Fate) and Power.

It should be also added that Tengrianism is not a prophetic religion, that is, not a religion proclaimed by someone, and not a "religion of salvation," but it is an original, traditional faith, a kind of worldview system based on the oral transfer of knowledge and without a written statement of doctrine, without a single Text, which would be attached sacral importance. Everything said to one degree or another distinguishes Tengrianism from all Abrahamic religions.

Spiritual culture of Turkic-speaking peoples "by virtue of its openness and universality, has always had the internal potential to preserve its identity and adaptive revival in the new civilizational conditions" [3, p. 13]. The plasticity of this culture was that nomads, discovering new religious systems, did not reject them, but, on the contrary, organically absorbed and processed them. Later religions assimilated autochthonous beliefs, elements of which, without being destroyed, became a part of a new religious tradition. So, in particular, in spiritual culture of Turkic-speaking peoples of the Crimea, various elements of Tengrianism are traced, the central systemic image of which is the highest and universal deity, the God of Heaven, Tengri (Tanry, Teiri, Tengiri).

For a long time, during which the formation of Turkic-speaking ethnic groups took place as a result of ethnocultural interactions, ideas about this highest sacred object were constantly exposed to various worldview systems.

In the context of traditional mythological ideas, Heaven is associated with the idea of top, light, good and fertility. It is credited with such properties as "remoteness, inaccessibility, immeasurability and constancy" [5, p. 271], which is directly related to its deification and worship of it as a deity, singular or supreme. According to M. Eliade, the history of the Higher Beings of the celestial structure is of paramount importance for understanding the history of religion of mankind as a whole. The sacralization of Heaven, which is characteristic to the culture of ancient peoples, is also due to such value characteristics attributed to it as transcendence and unattainability, greatness and superiority over all Earth's. People "believed that Heaven is inseparable from the very existence of a man and accompanies him from birth to death and ultimately determines his fate" [5, p. 271].

The mythological model of the world among the ancient Turks is a tripartite structure and it includes a system of antagonistic worlds: "the Blue Sky" (Kok Tengri) at the top, "The Brown Earth" at the bottom and "the Sons of Men" between them. The top of the vertical is Tengri. As A.A. Kodar notes in his works, "the religious worldview of nomads is cosmological, they do not separate themselves from the universe, from the entire space as a whole. In this regard, the God of Heaven is a part of the universe, he is also equally created like everything else. Nomadic consciousness... operates in a strategy of self-evident... everything is not creation for him, but self-creation. The idea of the God is needed for the nomad not in terms of the genesis of the world, but in terms of a powerful force that maintains a hierarchical order in the world" [9, p. 85]. 
The appeal to the archaic name of the God Tengri is characteristic for many Turkic peoples and dates back to the ancient Turkic tradition. N.G. Ayupov calls it a structureforming element of spiritual culture of these peoples. In the Old Turkic monuments of the Turkic Khaganate period, reflecting the lifestyle and belief system of the ancient Turks, there are mainly references to the name of the God Tengri, also found from the Gods Umai. The spirits of the Earth and Water noted several times, according to R.N. Bezertinov, should not be ranked among the deities.

The word "Tengri" was distinguished at the end of the 19th century by the Danish runologist Wilhelm Thomsen and "in the ancient Turkic written monuments and in the Dīwān Lughāt al-Turk of Mahmud Kashgari it is written as Тәңри. In different cultural traditions, preserving its basic meaning, it is written and read in different ways... In some Turkic languages Tengri is derived from two roots Тәң and pi, the first root means Heaven, the second means a man. In some cases, from the word ep (ip) it means a man" [12, p. 73]. In many languages of the world "Tenir," "Teniri," "Tengir" are used in meanings very close to various epithets of the God, the Creator.

In Crimean, as in most Turkic languages, the word "Tengri" means God and it is used when translating the Scriptures into Crimean (the practice that has been rooted since the beginning of the 18th century). According to I.V. Achkinazi, "vestiges associated with the Turkic deity Tengri, whose name is used by the Crimeans and in the religious Jewish cult, in offered prayers and in ancient funeral sacred songs" [2], can be considered as defining their religious tradition and one of the evidence of the presence of a Turkic-speaking core in the historical process of formation of the community of the Crimeans.

Veneration of "Tengri" is even more popular with the Crimean Karaites, in whose prayers, even despite the statement of Karaimism, "appeals to Tanry, Tengri along with Adonai and Alla continue to be preserved... As A.I. Polkanov notes, the term "Alla" is a manifestation of Islamic influence on the formation of the religious consciousness of the Crimean Karaites. Compared to the appeal to the Almighty "Tengri," "Alla" is of a later nature" [11, p. 72].

The monograph "Tengrian Civilization in the Spiritual, Cultural and Geopolitical Space of Central Asia" contains an indication that it is unacceptable to equate "Tengri" with Heaven as such, simply the Heavenly God or the Creator God, it is the unattainable and unrecognizable Absolute Truth, the Absolute Spirit, does not lend itself to a simple rational definition" [1, p. 47]. Only with a form of its existence, Tengri reveals to man transcendence, power, eternity. "Kok-Tengri (the Blue Sky) is not a material sky, opposed to the usual, visible sky. The appearance of Tengri is known to nobody. The concept of it was abstract. Tengri is a spirit. It was not represented as a human or an animal" [4]. He "controlled all events in the world, determined the fate of people, appointed everyone their lifetime" [8, $p$. 24].

A special place in spiritual culture of the Turks is occupied by faith in the Aruakhs (spirits of the ancestors). It should be noted that, to varying degrees of its development, this cult was known almost to all peoples. And here it is important to pay attention to the fact that among settled peoples it gradually disappears, and for the nomads it does not lose its significance and continues to be a systemically important element of their religious worldview.

The basis of the worldview of Tengrianism is the idea of the continuous flow of vitality and a man as a part of it. Human life originates in the sky, it is connected with it and returns to the sky. At the same time, a person throughout his life is accompanied by his double. It was believed that the "double" was born and grew up with a person, being inextricably connected with his body until his death. In the event of death, the double left the body and returned to the deity. "Turkic runic inscriptions speak of the deceased "ushty" - "flew away." Thus, he became an Aruakh, who now, as a part of the power of Heaven, watches and 
patronizes his offspring"[9, p. 87]. Nomads are characterized by a pre-individual religious feeling, which is a part of the "collective egregor and only in the worship of the Aruakh it is individualized in a certain way. But the deceased does not immediately become an Aruakh, it must take some time, after which the deceased ancestor turns into a symbol of the clan and a means of identifying it.... So that he could help, you don't even need prayer. It is enough to be filled with the spirit of the ancestor so that he will "get inside" you" [9, p. 89].

Another element of mythology of Turkic-speaking peoples is archaic beliefs associated with the cult of sacred trees [13, p. 24]. So, as a confirmation that the cult of sacred trees is not just a myth, in particular for the Crimean Karaites, we note that on the Crimea peninsula, not far from the Chufut-Kale fortress, there is a family cemetery, Balta Tiimez ("the ax will not touch"), in the territory of which several oaks are still preserved, the age of which dates back several centuries. This place is sacred to the Karaites, acts as a link with their past, the beliefs of their ancestors. It is believed that by showing respect for such a tree, a person showed his respect for the supreme Deity.

It was believed that violation or disobedience to the will of Tengri, and the lack of veneration of ancestors will entail cruel punishment in this life and on this Earth, and not after death in another world. "The God for the nomad is a formidable force that pacifies the wild forces of nature, but at the same time the God is no less threatening for a man" [9, $p$. 85]. Therefore, a man sought to find the mercy of the highest deity, capable of punishing, ruining not only him, but also his family, all his people. Atoning for guilt, calling the mercy of Tengri could be possible with the help of a ritual sacrifice.

The follower of Tengrianism began to learn and consolidate customs, rites, cult practice (prayers, rituals, sacrifices) in his mind. Partly due to this, according to researchers, Tengrianism had existed steadily in the same stable forms of ritual for more than one thousand years. "Regarding the Crimean Karaites, it can be noted that by changing Tengrianism to a new religion, they retained in everyday life the ritual component of early belief... It is not difficult to assume that if fragments of relict belief persisted in modern times, how much its influence was felt centuries earlier" [10].

Some authors as reasons for the longevity of Tengrianism point out such features of beliefs of the ancient Turks as high syncretism and the fact that religions that came later (Islam, Judaism, Karaimism) assimilated more ancient beliefs, which in one form or another were preserved, transforming, but continuing to play a significant role in spiritual culture of peoples and they are currently considered in the context of their historical, cultural and linguistic ties.

Thus, Tengrianism as one of the oldest beliefs, as an open worldview system, characterized by a specific idea of the place of a man in this world and the supreme deity managing everything, receiving one or another expression in religious tradition, retains its internal foundations and, in a transformed form, as separate elements, in many ways of ritual character (references to the God of Heaven, Tengri, in various modifications, veneration of ancestors and sacred trees), continues to act as an integral part of spiritual culture and cultural and civilizational self-identification of the Turkic peoples, which is also true of the Crimean Karaites, the Tatars and the Crimeans, who now live in the Republic of Crimea.

\section{Лumepamypa}

1. Абаев Н.В., Аюпов Н.Г. Тенгрианская цивилизация в духовно-культурном и геополитическом пространстве Центральной Азии. Абокан 2009 г., с. 47.

2. Ачкинази И.В. Крымчаки. Краткий очерк этнической истории // Сквозь века. Симферополь, 1996.

3. Аюпов Н.Г. Тенгрианство как открытое мировоззрение. Алматы: КазНПУ им. Абая. Издательство «КИЕ», 2012, 256 с. 
4. Безертинов Р.Н. Тэнгрианство - религия тюрков и монголов. Н. Челны: Аяз, 2000, Казань: Слово, 2004. 448 с.

5. Бурнаков В.А., Бурнаков А.А., Торбостаев К.М., Цыденова Д.Ц. Тигір тайығ жертвоприношение Небу в культуре хакасов (конец XIX - начало XXI века) // Вестник Новосибирского гос. унмверситета. Серия: История, филология. 2014. Т. 13, вып. 5: Археология и этнография. С. 271-283.

6. Вигель Н.Л., Жолобова И.К. Культура постмодерна: трансформация идеалов // Перспективы развития науки и образования. Сборник научных трудов по материалам XVIII международной научно-практической конференции. Москва, 2017. C. 106-107.

7. Жолобова И.К. Человек, его чувства и отношения в современных социокультурных реалиях // Перспективы развития науки и образования. Сборник научных трудов по материалам XXVIII международной научнопрактической конференции. Под общей редакцией А.В. Туголукова. 2018. С. 104-107.

8. Давлетшин Г.М. Очерки по истории духовной культуры предков татарского народа. Казань: Татарское книжное изд-во, 2004. 429 с.

9. Кодар А.А. Тенгрианство в свете номадологии Делеза-Гваттари // Новые исследования Тувы. 2009. № 4. С. 82-90.

10.Кропотов В.C. Специфика формирования этнической культуры крымских караимов и особенности ее проявления на различных исторических этапах развития общества / Святыни и проблемы сохранения этнокультуры крымских караимов. Материалы научно-практической конференции. Симферополь: Доля, 2008. С.109-149.

11. Кропотова Н.В. Общетюркские традиции фольклора крымских караимов // Проблемы современной науки и образования. 2017. С. 70-76.

12. Федорова Л.В. К вопросу идентичности концептов «язычества» славян, тенгрианства тюрков и монголов // CONCORDE. 2016. № 1. С. 72-88.

13. Zholobova $I$. The role of the religious component in the history of the formation of crimean karaim ethnoculture // Научный альманах стран Причерноморья. 2020. №2 (22). C. 21-27.

14. Vigel N., Zholobova I. Heroic epos of North Caucasus Nations as basis for ethnical culture of Adygea People // Научный альманах стран Причерноморья. 2017. №2 (10). C. 25-30.

\section{References}

1. Abaev N.V., Ayupov N.G. Tengrianskaia tsivilizatsiia $v$ dukhovno-kulturnom i geopoliticheskom prostranstve Tsentralnoi Azii. [Tengrian civilization in the spiritual, cultural and geopolitical space of Central Asia]. Abokan, 2009, 47 p. (in Russian).

2. Achkinazi I.V. Krymchaki. Kratkii ocherk etnicheskoi istorii. Skvoz veka. [The Crimeans. A short essay on ethnic history. Through the ages]. Simferopol, 1996 (in Russian).

3. Ayupov N.G. Tengrianstvo kak otkrytoe mirovozzrenie. [Tengrianism as an open worldview]. Almaty: KNPU named after Abay. Publishing house "KIE," 2012, 256 p. (in Russian).

4. Bezertinov R.N. Tengrianstvo - religiia tiurkov i mongolov. [Tengrianism is the religion of the Turks and the Mongols]. Naberezhnye Chelny: Ayaz, 2000, Kazan: Slovo, 2004. 448 p. (in Russian).

5. Burnakov V.A., Burnakov A.A., Torbostaev K.M., Tsydenova D.C. Тигір тайығ zhertvoprinoshenie Nebu v kulture khakasov (konets XIX - nachalo XXI veka). [Тигір 
тайығ - sacrifice to Heaven in the Khakass culture (late 19th - early 21st centuries)]. Bulletin of Novosibirsk State University. Series: History, philology. 2014. V.13, Issue 5: Archeology and ethnography. pp. 271-283 (in Russian).

6. Vigel N.L., Zholobova I.K. Kultura postmoderna: transformatsiia idealov. V sbornike: Perspektivy razvitiia nauki i obrazovaniia. Sbornik nauchnykh trudov po materialam XVIII mezhdunarodnoi nauchno-prakticheskoi konferentsii. [Post-modern culture: the transformation of ideals. In the collection: Prospects for the development of science and education. Collection of scientific papers on the materials of the XVIII international scientific and practical conference]. Moscow, 2017, pp. 106-107 (in Russian).

7. Zholobova I.K. Chelovek, ego chuvstva i otnosheniia v sovremennykh sotsiokulturnykh realiiakh. $\mathrm{V}$ sbornike: Perspektivy razvitiia nauki i obrazovaniia. Sbornik nauchnykh trudov po materialam XXVIII mezhdunarodnoi nauchnoprakticheskoi konferentsii. [Man, his feelings and relationships in modern sociocultural realities. In the collection: Prospects for the development of science and education. Collection of scientific papers on the materials of the XXVIII International Scientific and Practical Conference]. Under the general editorship of A.V. Tugolukov. 2018, pp. 104-107 (in Russian).

8. Davletshin G.M. Ocherki po istorii dukhovnoi kultury predkov tatarskogo naroda. [Essays on the history of the spiritual culture of the ancestors of the Tatar people]. Kazan: Tatar Book Publishing House, 2004. 429 p. (in Russian).

9. Kodar A.A. Tengrianstvo v svete nomadologii Deleza-Gvattari. Novye issledovaniia Tuvy. [Tengrianism in the light of the nomadology of Deleuze-Guattari. New studies of Tuva]. 2009. No. 4. pp. 82-90 (in Russian).

10. Kropotov V.S. Spetsifika formirovaniia etnicheskoi kultury krymskikh karaimov i osobennosti ee proiavleniia na razlichnykh istoricheskikh etapakh razvitiia obshchestva. Sviatyni i problemy sokhraneniia etnokul'tury krymskikh karaimov. Materialy nauchno-prakticheskoi konferentsii. [Specifics of the formation of the ethnic culture of the Crimean Karaites and the peculiarities of its manifestation at various historical stages of the development of society. Shrines and problems of preserving the ethnoculture of the Crimean Karaites. Materials of the scientific and practical conference]. Simferopol: Dolia, 2008, pp. 109-149 (in Russian).

11. Kropotova N.V. Obshchetiurkskie traditsii folklora krymskikh karaimov. Problemy sovremennoi nauki i obrazovaniia. [General Turkic traditions of Crimean Karaite folklore. Problems of modern science and education]. 2017, pp. 70-76 (in Russian).

12. Fedorova L.V. K voprosu identichnosti kontseptov "iazychestva" slavian, tengrianstva tiurkov i mongolov. [On the question of the identity of the concepts of "heathenry" of the Slavs, Tengrianism of the Turks and the Mongols]. CONCORDE. 2016. No. 1. pp. 72-88 (in Russian).

13. Zholobova I. The role of the religious component in the history of the formation of crimean karaim ethnoculture. Science Almanac of Black Sea Region Countries. 2020. No. 2 (22). pp. 21-27.

14. Vigel N., Zholobova I. Heroic epos of North Caucasus Nations as basis for ethnic culture of Adygea People. Science Almanac of Black Sea Region Countries. 2017. No. 2 (10). pp. 25-30. 